\title{
Spastic Paraplegia with SPG11 Gene delE39 in a Turkish Patient
}

\author{
SPG11 Geninde delE39 Saptanan Türk Hasta
}

Zeynep Öztürk ${ }^{1}$, Cengiz Havalı², Ercan Demir ${ }^{3}$, Kıvılcım Gücüyener ${ }^{3}$

${ }^{1}$ Gazi University, Faculty of Medicine, Department of Pediatric Neurology, Ankara, Turkey

${ }^{2}$ Bursa Sevket Yilmaz Training and Research Hospital, Department of Pediatric Neurology, Bursa, Turkey

${ }^{3}$ Gazi University, Faculty of Medicine, Department of Pediatric Neurology, Ankara, Turkey

\section{ABSTRACT}

Hereditary spastic paraplegias (HSPs) are a heterogeneous group of inherited neurodegenerative disorders leading to progressive spasticity of the lower limbs. HSPs are divided into autosomal dominant (AD), autosomal recessive $(A R)$ and $X$-linked (XL) forms. ARHSP with thin corpus callosum (TCC) is a frequent subtype characterized by progressive spastic paraparesis, cognitive impairment and thin corpus callosum. We report a 16 years old male patient presented with weakness and paraplegia of lower limbs and mental retardation. He had near normal motor and mental development until 11 years of age, afterwards he had progressive cognitive and learning impairment also difficulty in walking. His neurological examination revealed hyperreflexia, increased tonus and severe sapasticity of lower extremities, contractures in toes, ankles and knees. He also had extensor plantar responses, bilateral pes cavus. His cranial MRI showed thin corpus callosum. His genetic test result showed deIE39 in SPG11 gene.

Key Words: Hereditary spastic paraplegias, corpus callosum, children, cerebral palsy

Received: 08.09.2016

Accepted: 09.07.2016

\section{ÖZET}

Herediter spastik parapleji (HSP) heterojen, genetik ve nörodejeneratif bir hastalık grubudur. Alt ekstremitede progresif olarak gelişen spastisite ile karakterizedir. Otozomal dominant, otozomal resesif ve $X^{\prime}$ e bağlı kalıtılan formları vardır. HSP ile ince korpus kallozum birlikteliği otozomal resesif kalıtım ve progresif spastik paraparezi, kognitif yıkım ve ince korpus kallozum ile karakterizedir. 16 yaşında alt ekstremitede güçsüzlük ve zeka geriliği nedeniyle başvuran erkek hasta sunuldu. 11 yaşına kadar yaşına uygun mental ve motor gelişimi olan hastanın sonrasında progresif olarak ilerleyen kognitif fonksiyonlarda gerileme ve yürüme bozukluğu başlamıştı. Nörolojik muayenede alt ekstremitede derin tendon refleksleri canlı, tonus artışı ve ciddi spastisite vardı. Ayrıca, muayene bulgularına bilateral babinski pozitifliği ve pes kavus eşlik ediyordu. Kranial manyetik rezonans incelemede ince korpus kallozum izlendi. Genetik analiz sonucu SPG11 geninde 39. ekzon bölgesinde delesyon (delE39) saptandı.

Anahtar Sözcükler: Herediter spastik parapleji, korpus kallozum, çocuk, serebral palsi

Geliş Tarihi: 09.08.2016

Kabul Tarihi: 07.09.2016

\section{INTRODUCTION}

Hereditary spastic paraplegia (HSP) is a clinically and genetically heterogeneous neurodegenerative disorders. HSP is classified due to its clinical manifestation. In pure form, patients present with weakness and spasticity of lower limbs. In complicated forms, additonally skeletal deformity, optic atrophy, extrapyramidal signs, seizures, cerebellar signs and intellectual disability may also be present. Autosomal dominant, autosomal recessive (AR) and $X$ linked forms have been reported (1).

Herditary spastic paraplegia with thin corpus callosum (HSP-TCC) (MIM 604360 ) is the most common type of complicated HSP characterized by slowly progressive spastic paraparesis and cognitive decline (2). Disease onset occurs during puberty or adolescence. Most of mutations have autosomal recessive inheritance. Its clinical manifestation include seizures, peripheral neuropathy, cerebellar ataxia, extrapyramidal signs and skeletal deformitiy. Remarkable thinning corpus callosum is detectable in brain magnetic resonance imaging (MRI). It is genetically heterogeneous disorder.
SPG11 is most common genetic form and SPG11 was mapped to chromosome 15q13-15 which encodes the spatacsin protein (3).

We report a 16 years old male patient presented with weakness and paraplegia of lower limbs and mental retardation and also had SPG11 mutation.

\section{CASE REPORT}

A sixteen year old boy born to a second degree consanguineous marriage was admitted to our clinic because of progressive bilateral weakness in lower extremities and cognitive impairment. He had near normal motor and mental development until the age of 11 , afterwards he had progressive cognitive impairment, learning and walking difficuties which finally led him to walking with aid. Neurological examination revealed brisk reflexes, increased tonus and severe sapasticity of lower extremities, contractures in toes, ankles and knees. He had bilateral babinski sign and bilateral pes cavus. Bilateral fundus were normal. 
Laboratory tests included normal complete blood count, glucose, electrolytes, thyroid function tests, serum vitamin B12, folic acid, plasma lactate level, urine organic acid and blood amino acid level, tandem mass spectroscopy. Brain MRI showed a remarkable TCC. Exclusion of other diagnosis and the combination of severe TCC, spastic papaparesia and cognitive impairment made us to perform the mutation analysis for SPG11, a common cause of HSP-TCC. DNA was extracted from peripheral blood sample. Coding exons of the SPG11 gene were screened by multiplex ligation dependent probe amplification analyse (MLPA). The deletion has been detected on 39. exon region of $15 q 21.1$. For spasticity of lower extremities baclofen treatment has been started and an exercise programme planned by a physiotherapist.

\section{DISCUSSION}

HSP-TCC has been first described in Japan (4). It is more wide spread than previously been believed and the pattern of AR inheritance is observed frequently because of consanguineous marriages. Clinical features are characterized by slowly progressive spastic paraplegia with cognitive decline and upper limb spasticity, cerebellar signs, pes cavus, peripheral neuropathy, extrapyramidal signs, ocular involvement. In recent studies reported, it may also be seen rare phenotype of HSP with SPG11 mutations associated with juvenil parkinsonism and are responsive L-Dopa (5). Our patient had similar clinical phenotype and imaging manifestations with previously reported cases. The patient had progressive spastic paraparesis and cognitive decline with TCC. The symptoms were noticed in early teenage. The age of onset of symptoms are mostly in the second decade of life.

HSP-TCC is the most common phenotype of complex HSP. SPG11 is the most frequent genotype and second common genotype is SPG15. Other mutations SPG21, FA2H, GBA2, AP5Z1 and DDHD2 may also present with HSP-TCC. So far, non-sense mutations, small deletions and small insertions have been reported. Because of genetic and phenotypic heterogenitiy of HSP-TCC, with several causative loci, it is challenging to determine an optimal screening strategy for genetic diagnosis. Therefore, we performed only SPG11 analysis by MLPA method which led to the identification of the most common HSP-TCC genotype. So far, 67 mutations in the SPG11 gene have been reported (6). We reported a deletion on exon 39 associated with HSPTCC. This mutation has been identified in previous studies (6). However limited data available in Turkey. Gucuyener et al described HSP with hypoplastic corpus callosum in 3 siblings from healthy consanguineous parents. But there were no genetic results (7). To our knowledge it is the first case carrying this mutation in Turkey.

Involvement of the brain such as TCC has been described in SPG11. Other abnormalities include cortical atrophy, hyperintensity in periventricular white matter and ventricular dilatation. Pensato et al. reported 22 case series with SPG11 gene mutations had moderate to severe TCC. Afterwards, white matter hyperintensity, ventricular enlargment and mild reduction of the cerebral white matter have been showed in brain MRI (8). According to the literature for HSP-TCC, intellectual disabilities are present in all individuals with SPG11 mutation. The patient had mild cognitive impairment and this result was similar with other studies. Therefore it should be done all affected patients.

\section{CONCLUSION}

The symptoms of HSP are very similar to cerebral palsy (CP), but progressive clinical features could help distinguish from CP. The correct diagnosis is very important for genetic counceling. Higher frequency of SPG11 compared with SPG15 and other genotypes and because of genetic heterogenity we suggest testing SPG11 and then analysis of SPG15 to negative cases. Further studies are needed to understand the genetic profile of this disorder in Turkey.

Conflict of interest

No conflict of interest was declared by the authors
REFERENCES

1.Winner B, Uyanik G, Gross C, Lange M, Schulte-Mattler W, Schuierer G, et al. Clinical progression and genetic analysis in hereditary spastic paraplegia with thin corpus callosum in spastic gait gene 11 (SPG11). Archives of neurology. 2004;61:117-21.

2.Samaranch L, Riverol M, Masdeu JC, Lorenzo E, Vidal-Taboada JM, Irigoyen $\mathrm{J}$, et al. SPG11 compound mutations in spastic paraparesis with thin corpus callosum. Neurology. 2008;71:332-6.

3.Lossos A, Stevanin G, Meiner V, Argov Z, Bouslam N, Newman JP, et al. Hereditary spastic paraplegia with thin corpus callosum: reduction of the SPG11 interval and evidence for further genetic heterogeneity. Archives of neurology. 2006;63:756-60.

4.Iwabuchi K, Kubota Y, Hanihara T, Nagatomo H. [Three patients of complicated form of autosomal recessive hereditary spastic paraplegia associated with hypoplasia of the corpus callosum]. No to shinkei = Brain and nerve. 1994;46:941-7.

5. Everett CM, Kara E, Maresh KE, Houlden $\mathrm{H}$. Clinical variability and L-Dopa responsive Parkinsonism in hereditary spastic paraplegia 11 . Journal of neurology. 2012;259:2726-8.

6.Denora PS, Schlesinger D, Casali C, Kok F, Tessa A, Boukhris A, et al. Screening of ARHSP-TCC patients expands the spectrum of SPG11 mutations and includes a large scale gene deletion. Human mutation. 2009;30:E500-19. 7.Gucuyener K, Hirfanoglu T, Ok I, Cansu A, Serdaroglu A. Hereditary spastic paraplegia with hypoplastic corpus callosum in a Turkish family. Journal of child neurology. 2007;22:214-7.

8.Pensato V, Castellotti B, Gellera C, Pareyson D, Ciano C, Nanetti L, et al. Overlapping phenotypes in complex spastic paraplegias SPG11, SPG15, SPG35 and SPG48. Brain : a journal of neurology. 2014;137(Pt 7):1907-20.

9.Cao L, Rong TY, Huang XJ, Fang R, Wu ZY, Tang HD, et al. Novel SPG11 mutations in Chinese families with hereditary spastic paraplegia with thin corpus callosum. Parkinsonism \& related disorders. 2013;19:367-70. 